\title{
Agencies anxious as US Congress fixes deadline for 1988 budget
}

\section{Washington}

US SCIENCE agencies are watching anxiously as Congress enters the home stretch of the 1988 budget process. Although the financial year began officially on 1 October, Congress has given itself until mid-November to make all its outstanding spending decisions for 1988 .

Many agencies are enjoying a period of cautious optimism as the final decisions draw near. But there remains the threat that last-minute compromises to balance the books could radically alter the financial landscape. And if that were not enough to cause sleepless nights in budget offices throughout Washington, there is also the spectre of automatic cuts brought on by the modified Gramm-RudmanHollings deficit reduction act.

Both the House of Representatives and the Senate have now completed work on the National Science Foundation (NSF) budget, but differences will have to be worked out by a joint House-Senate conference. The Senate appeared ready to make significant cuts in NSF's budget (see Nature 328, 749; 1987) when, at the last moment, extra money was found.

The Senate appropriation for NSF now stands at $\$ 1,867$ million, just slightly under the administration's request. The House appropriation is $\$ 1,796$ million. The House version cuts NSF research money, but increases funds for science education. The Senate reduces the amount for NSF Antarctic programmes.

The National Institutes of Health (NIH) have received their accustomed increase from Congress, with the result that the budget is well ahead of the Reagan administration's request. Excluding money for research on AIDS, the House would provide $\mathrm{NIH}$ with $\$ 6,563.9$ million and the Senate $\$ 6,388.2$ million. For AIDS research, the House adds $\$ 472.4$ million and the Senate $\$ 487.9$ million.

According to Katherine Bick, NIH deputy director for extramural research and training, the amounts proposed should allow between 6,200 and 6,400 new research awards to be made, although the usual trimming of individual financial awards may be slightly larger than usual.

Both House and Senate bills contain money for the National Institute of General Medical Sciences specifically for the project to construct a genetic and physical map of the human genome, but the House version provides $\$ 30$ million compared with $\$ 6$ million in the Senate.

For the National Aeronautics and Space Administration (NASA), the biggest question mark is the space station. The Senate bill provides some $\$ 200$ million less than the requested $\$ 767$ million.
Should the Senate version prevail, the programme would suffer a severe setback. US negotiators are still trying to nail down agreements with Japan, Canada and the European Space Agency on participation in the project. Those agreements must be reached soon, or hardware development and production will be delayed.

It is still unclear how the final budget plans will be translated into law, as there is not enough time for conferences to resolve all the differences between the various versions of the appropriations bills. All the appropriations could be incorporated into a single, giant spending bill. But putting all the eggs in one basket often pits Congress against the president in a test of wills, as the president has vetoed budgets he is not happy with.

Both House and Senate are also looking at ways to raise taxes to provide the revenue that will be needed to keep the deficit from growing even faster than at present, but the White House has adamantly opposed increased taxes as a way of shrinking the deficit. The revised Gramm-Rudman law passed last month forces spending to be curtailed, but the new targets are not as stringent as those in an earlier version. The law calls for a deficit cap of $\$ 144,000$ million for 1988 , but restricts automatic cuts to $\$ 23,000$ million. If the automatic cuts take place, agency budgets could be reduced from 3 to 8 per cent.

\section{Tough bargaining ahead on European space programmes}

\section{London \& Paris}

THERE are increasing indications that next month's ministerial meeting of the European Space Agency (ESA) in The Hague will not be the formality for which officials are hoping. Last week, the British government stated for the first time publicly that it would be seeking to persuade the meeting to adopt a less ambitious programme for the next decade - current plans are for an integrated package of elements comprising a heavy-lift rocket launcher (Ariane V), a space platform (Columbus) and a shuttle vehicle (Hermes). Adoption of the proposals would mean an increase

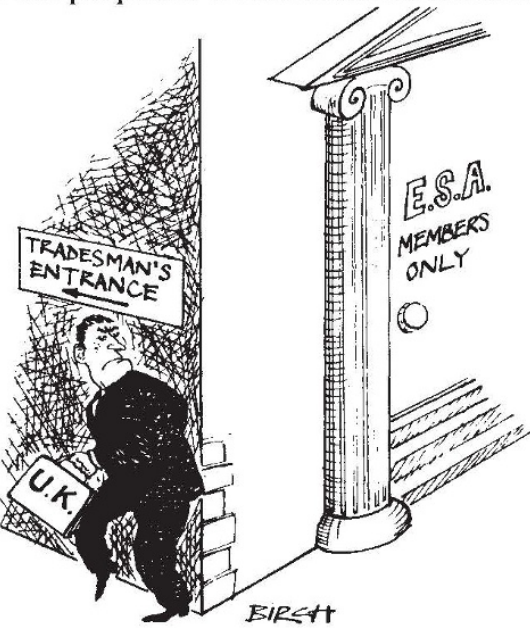

in ESA's $£ 1,000$ million budget from 70 to 100 per cent.

Britain has already said that it will not increase its contribution, with Kenneth Clarke, the minister responsible for Britain's space programme, describing ESA as a hugely expensive club with overambitious programmes. Last week, Clarke's number two at the Department of Trade and Industry, John Butcher, told space industrialists in Brighton that "we think ESA's proposals are expensive and not all of the present proposals need to be decided now. We believe they should rethink their proposals and see if they can instil a more commercial slant into their operations."

Furthermore, Butcher claimed that the government's concern about "the trend in ESA towards widening development objectives, with apparently diminishing regard for commercial realities" is not Britain's alone. "We are saying publicly what other governments are saying privately." There are indications that West Germany, for one, would like to see the ESA meeting postpone adoption of the development phase of Hermes until the next decade. ESA officials in Paris are reluctant to comment on the British government's position. The hope within ESA is that any doubtful governments will be convinced at the meeting of the need for the expanded programme. The more optimistic recall the spontaneous enthusiasm at the last ministerial meeting in 1982 when the design phases of the three big programmes were adopted.

Expanding investment in space, particularly by the Soviet Union but also by Japan and the United States, will be cited as one of the main reasons for the need for European cohesion in space. One feeling within Britain is that Clarke and Butcher have timed their announcements carefully to serve as a shot across ESA's bows that tough negotiations lie ahead.

Meanwhile, agreement has still not been reached on collaboration between ESA and NASA on the international space station (see above). Intervention by the US Department of Defense has made it difficult for governments to agree on terms for the collaboration.

Simon Hadlington \& Peter Coles 